TECHNICAL TRANSACTIONS 5/2017

CZASOPISMO TECHNICZNE 5/2017

MECHANICS

DOI: $10.4467 / 2353737$ XCT.17.080.6437

Sebastian Pater (sebapater@chemia.pk.edu.pl)

Włodzimierz Ciesielczyk

Faculty of Chemical Engineering and Technology, Cracow University of Technology

\title{
REAL AND THEORETICAL ENERGY EFFICIENCY \\ OF VAPOUR COMPRESSION HEAT PUMPS
}

RZECZYWISTA I TEORETYCZNA WYDAJNOŚĆ ENERGETYCZNA

PAROWYCH SPRĘŻARKOWYCH POMP CIEPŁA

\begin{abstract}
This paper presents several ways of calculating real and theoretical energy efficiency coefficients of vapour compression heat pumps in short and long time. Differences in the calculation are associated with taking into account, among others, various components of the heat pump responsible for the consumption of electricity, steady state or transient conditions, part or the nominal load ratio of heat pump. The calculation results are compared with the values of coefficients, which have been obtained theoretically.
\end{abstract}

Keywords: heat pump, seasonal performance factor, seasonal coefficient of performance

\section{Streszczenie}

W artykule przedstawiono kilka sposobów obliczania teoretycznych i rzeczywistych wartości współczynników wydajności parowych sprężarkowych pompy ciepła w krótkim i długim okresie. Różnice w obliczeniach związane są między innymi z uwzględnianiem różnych składowych odpowiedzialnych za konsumpcję energii elektrycznej w pompie ciepła, czy rozpatrywany jest stan ustalony czy nieustalony oraz czy pompa ciepła pracuje z nominalnym czy częściowym obciążeniem. Wyniki obliczeń porównano z wartościami współczynników, które zostały określone na drodze teoretycznej.

Słowa kluczowe: pompa ciepła, sezonowy współczynnik wydajności, sezonowy współczynnik efektywności 


$\begin{array}{ll}\text { Abbreviations } \\ \text { RES - } & \text { renewable energy sources } \\ \mathrm{CH}- & \text { central heating } \\ \mathrm{DHW}- & \text { domestic hot water } \\ \mathrm{BHS}- & \text { bottom heat source } \\ \mathrm{SPF}- & \text { seasonal performance factor } \\ \mathrm{COP}- & \text { coefficient of performance } \\ \mathrm{SCOP}- & \text { seasonal coefficient of performance } \\ \mathrm{ErP} \quad- & \text { energy related products }\end{array}$

\section{Introduction}

In the $21^{\text {st }}$ century, because of the necessity to reduce the greenhouse effect and global warming, development of environmentally friendly heating and cooling technologies based on renewable energy sources (RES) is much required [1]. In this context, heat pumps play a key role in the supply of efficient and clean energy from our surroundings. Moreover, heat pumps can satisfy highly specific requirements for heating and processing heat in industry and commerce, while simultaneously being economically attractive and environmentally compatible alternative to conventional heating systems [2].

The European and Polish market of heat pumps is one of the most dynamically developing branches of RES [3]. This is very important in a period of increased international interaction in the field of environmental protection and proposals for increasing the share of RES in the national economies, both European Union countries, as well as on the global scale. A crucial for the development of heat pump market in Poland was document laying down guidelines for the calculation of renewable energy share from heat pumps for the different technology on the basis of Art. 5 of the European Parliament and Council Directive 2009/28/EC [4]. Also of great importance is the Renewable Energy Sources Act (OJ 2015 pos. 478) accepted on the $20^{\text {th }}$ of February 2015, establishing fundamental changes in the system of support for energy from unconventional sources.

For reliable assessment of economic as well as environmental efficiency of heat pump operation in heating and/or cooling mode is needed knowledge of its energy efficiency. Because efficiency, understood as measure of the extent to which input is well used for an intended task or function, cannot exceed values greater than unity in the heat pump technology was developed a number of coefficients [5].

\subsection{1. Performance coefficients in the heating mode of heat pump}

One of the key parameters for evaluating the performance of the heat pump in heating mode is the COP (Coefficient OfPerformance, in German: Leistungszahl) [6]. This coefficient for compression heat pumps expresses the ratio of heat output and power consumption in 
clearly defined and specified operating conditions. It can be calculated from measurements in laboratory tests from formula (1):

where

$$
\mathrm{COP}=\frac{Q}{P_{m}}
$$

Q - the heat power of heat pump $[\mathrm{W}]$,

$P_{m} \quad$ - electric power consumed by the compressor, safety and control components and also devices responsible for flow of factors which intermediary in the heat transfer inside the heat pump $[\mathrm{W}]$.

Precise definition of the procedure for determining COP in certified laboratories is largely standardised throughout Europe on the basis of the EN 14511 [07]. Rating is carried out under steady state conditions (depending on the manufacturer's needs and the type of the unit) and at full capacity of the heat pump [8]. The main differences between the previous standard EN 255 and the current is the mass flow rate set to produce a $5 \mathrm{~K}$ temperature difference on the heating side (previous $10 \mathrm{~K}$ ) and taking into account the electricity consumption of the circulation pump to overcome the hydraulic resistance of the liquids through the condenser [9].

The analyses of energy efficiency of vapour compression heat pumps and their impact on the environment more reliable parameter is the coefficient determining the efficiency of the heat pump over a longer period of time (usually during one year or a one heating season). In the scientific journals [5, 9 and 10] can be meet several coefficients for estimating the seasonal performance factor of the heat pumps (Table 1).

Table 1. Coefficients for estimating the seasonal performance factor

\begin{tabular}{|c|c|c|}
\hline Abbreviation & Description & Standard \\
\hline SCOP & Seasonal Coefficient OfPerformance & EN 14825 \\
\hline SPF & Seasonal Performance Factor & EN 15316 \\
\hline HSPF & Heating Seasonal Performance Factor & ASHRAE 116 \\
\hline JAZ & Jahresarbeitszahl & VDI 4650 \\
\hline
\end{tabular}

The most commonly cited factor is the SCOP, which is the parameter forming basis for an eco-design, European minimum requirements and energy labelling of heat pumps. Standard EN 14825 contains description of the calculation method of SCOP and the part load conditions for three different climates (an average climate, one cold and one warm climate) [11]. The standard is applicable to factory-made units defined in EN 14511.

SCOP calculation's is based on the temperature bin method (i.e. dividing the heating season into a number of hours with different temperatures) and taking into account [12]:

- electricity consumption by an additional electric heater,

- electricity consumption of heat pump during operation in standby mode,

- operating conditions, i.e. different climatic conditions and dynamic changes of heat demand for central heating $(\mathrm{CH})$ and domestic hot water (DHW) production in time, 
- part and the nominal load ratio of heat pump.

From the $26^{\text {th }}$ of September 2015, all heating devices with an output equal to or less than $400 \mathrm{~kW}$ are affected by the Energy related Products (ErP) directive [13], which comprises Ecodesign and Energy Labelling directive. The main ErP directive goal is to improve energy efficiency and environmental protection by prompting manufacturers to offer products designed to reduce their overall impact on the environment, to increase the use of RES and to enable consumers to make informed choices.

In order to compare devices with different heat production technologies is applied factor expressed in \% known as seasonal space heating energy efficiency. It is defined as (2):

$$
\eta_{s}=\frac{\mathrm{SCOP}}{\mathrm{CC}}-\sum F_{i}
$$

where

$$
\begin{aligned}
& \text { CC - conversion coefficient }[-], \\
& F-\text { correction factor [\%]. }
\end{aligned}
$$

For heat pumps with electrically driven compressors, a conversion factor of 2.5 is used on the assumption that it takes 2.5 energy units of primary fuel to produce 1 energy unit of electricity (efficiency of electricity production and distribution is approximately equal $40 \%$ in EU) [14]. Products complying with the ErP are identified by an energy label (Table 2 ) with an efficiency band between $\mathrm{A}+++$ to $\mathrm{G}$ (with $\mathrm{A}+++$ being the highest performing product, the worst $\mathrm{G}$ ). Deciding factors, in the assigning heat pumps to individual classes in energy labels, are the SCOP factor and also the reference supply temperature (for the low temperature heating system $35^{\circ} \mathrm{C}$ and for high temperature heating system $55^{\circ} \mathrm{C}$ ).

Table 2. Coefficients for estimating the seasonal performance factor

\begin{tabular}{|c|c|c|c|c|}
\hline $\begin{array}{c}\text { Energy } \\
\text { class }\end{array}$ & \multicolumn{2}{|c|}{ Low temperature heating system } & \multicolumn{2}{c|}{ High temperature heating system } \\
\hline $\mathrm{A}+++$ & $\mathrm{SCOP}>4.38$ & $\eta_{\mathrm{s}}>175$ & $\mathrm{SCOP}>3.75$ & $\eta_{\mathrm{s}}>150 \%$ \\
\hline $\mathrm{A}++$ & $3.75 \leq \mathrm{SCOP}<4.38$ & $150 \% \leq \eta_{\mathrm{s}}<175 \%$ & $3.13 \leq \mathrm{SCOP}<3.75$ & $125 \% \leq \eta_{\mathrm{s}}<150 \%$ \\
\hline $\mathrm{A}+$ & $3.08 \leq \mathrm{SCOP}<3.75$ & $123 \% \leq \eta_{\mathrm{s}}<150 \%$ & $2.45 \leq \mathrm{SCOP}<3.13$ & $98 \% \leq \eta_{\mathrm{s}}<125 \%$ \\
\hline A & $2.88 \leq \mathrm{SCOP}<3.08$ & $115 \% \leq \eta_{\mathrm{s}}<123 \%$ & $2.25 \leq \mathrm{SCOP}<2.45$ & $90 \% \leq \eta_{\mathrm{s}}<98 \%$ \\
\hline B & $2.68 \leq \mathrm{SCOP}<2.88$ & $107 \% \leq \eta_{\mathrm{s}}<115 \%$ & $2.05 \leq \mathrm{SCOP}<2.25$ & $82 \% \leq \eta_{\mathrm{s}}<90 \%$ \\
\hline C & $2.50 \leq \mathrm{SCOP}<2.68$ & $100 \% \leq \eta_{\mathrm{s}}<107 \%$ & $1.88 \leq \mathrm{SCOP}<2.05$ & $75 \% \leq \eta_{\mathrm{s}}<82 \%$ \\
\hline $\mathrm{D}$ & $1.55 \leq \mathrm{SCOP}<2.50$ & $61 \% \leq \eta_{\mathrm{s}}<100 \%$ & $0.93 \leq \mathrm{SCOP}<1.88$ & $37 \% \leq \eta_{\mathrm{s}}<75 \%$ \\
\hline E & $1.48 \leq \mathrm{SCOP}<1.55$ & $59 \% \leq \eta_{\mathrm{s}}<61 \%$ & $0.85 \leq \mathrm{SCOP}<0.93$ & $34 \% \leq \eta_{\mathrm{s}}<37 \%$ \\
\hline F & $1.38 \leq \mathrm{SCOP}<1.48$ & $55 \% \leq \eta_{\mathrm{s}}<59 \%$ & $0.75 \leq \mathrm{SCOP}<0.85$ & $30 \% \leq \eta_{\mathrm{s}}<34 \%$ \\
\hline G & $\mathrm{SCOP}<1.38$ & $\eta_{\mathrm{s}}<55 \%$ & $\mathrm{SCOP}<0.75$ & $\eta_{\mathrm{s}}<30 \%$ \\
\hline
\end{tabular}

*SCOP calculated for $\sum F_{i}$ equal 0 


\subsection{Coefficients in real conditions}

It is important to verify the estimated value of the SCOP in the system operated in real conditions. The factor used for the calculating real seasonal performance factor of the heat pump in heating mode is called SPF [15]. There is a certain inaccuracy because the same abbreviation is used for the estimation performance factor according to EN 15316.

The methodology of measuring and calculating the SPF is not consistent and unambiguous [16]. The biggest differences are associated with taking into account various components responsible for the consumption of electricity by the heat pump (e.g. the circulation pumps, regulators, controllers, electric heaters) [16]. In the project "WP-Effizienz", in which the analysis of 110 heat pump systems of various types since July 2007 to June 2010 have been conducted, an attempt to standardise the calculation of SPF in real conditions was made [17, 18 and 19]. The graphic interpretation of the boundaries determining SPF coefficients is shown in Figure 1.

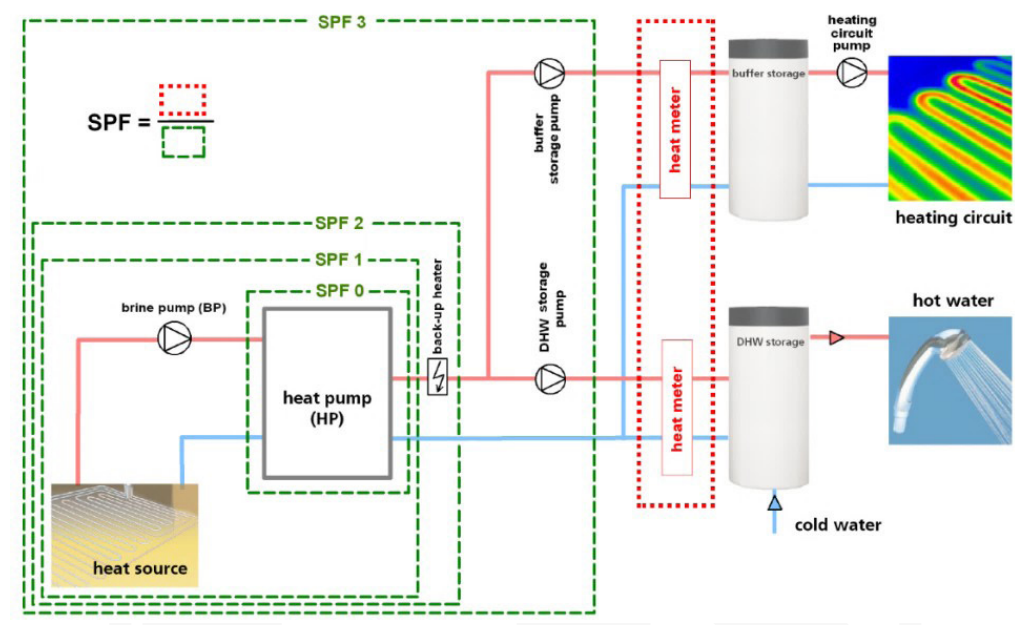

Fig. 1. The graphic interpretation of the boundaries determining SPF coefficients [19]

In this work [19] was proposed four formulas to calculate SPF in heating mode of heat pump (3-6):

$$
\begin{gathered}
\mathrm{SPF} 0=\frac{Q_{S}}{P_{C}} \\
\mathrm{SPF} 1=\frac{Q_{S}}{P_{C}+P_{P}} \\
\mathrm{SPF} 2=\frac{Q_{S}+Q_{E}}{P_{C}+P_{P}+P_{E}}
\end{gathered}
$$




$$
\text { SPF3 }=\frac{Q_{S}+Q_{E}}{P_{C}+P_{P}+P_{E}+P_{O}}
$$

where

$Q_{S}$ - heating energy produced by heat pump in heating season [J],

$Q_{E}$ - energy produced by electric back-up heater in heating season [J],

$P_{C}$ - energy consumed by compressor and control unit in heating season $[\mathrm{J}]$,

$P_{P}$ - energy consumed by brine or well pump and fans in heating season $[\mathrm{J}]$,

$P_{E}$ - energy consumed by electric back-up heater in heating season [[J],

$P_{O}$ - energy consumed by charge pumps in heating season [J].

The first two SPF do not provide full information about the energy efficiency of the heating system with a heat pump. The difference between SPF2 and SPF3 lies in taking into account the amount of electricity consumed by the circulation pumps transporting heat from the heat pump to the buffer tank and/or hot tap water tank.

The aim of this work is to compare theoretical performance coefficients for vapour compression heat pump from the manufacturer's technical data with SPF factors obtained in real conditions.

\section{Building and installation features}

Table 3 presents basic technical data of geothermal brine-water heat pump, which has been used in the CH and DHW installation in a building with a floor area of $460 \mathrm{~m}^{2}$ near Cracow. Several rooms in the building's ground floor serve as office space, while the remainder are residential. The heat pump covers only the heat demand for $\mathrm{CH}$. The $\mathrm{CH}$ system consists of a convection heaters and air handling unit with 5 air heaters.

Table 3. Technical data of heat pump used in the installation

\begin{tabular}{|c|c|c|}
\hline Conditions according to EN 14511 & B0/W35* & B0/W55 \\
\hline Heating power $[\mathrm{kW}]$ & 10.4 & 9.5 \\
\hline Electric power consumption $[\mathrm{kW}]$ & 2.4 & 3.3 \\
\hline COP $[-]$ & 4.4 & 2.9 \\
\hline \multirow{2}{*}{ Energy class according to ErP } & $\begin{array}{c}\text { Low temperature } \\
\text { heating system }\end{array}$ & $\mathrm{A}++$ \\
\cline { 2 - 3 } & $\begin{array}{c}\text { High temperature } \\
\text { heating system }\end{array}$ & $\mathrm{A}++$ \\
\hline
\end{tabular}

${ }^{*} \mathrm{~B}$ - brine inlet temperature in evaporator, $\mathrm{W}$ - water inlet temperature in condenser

The bottom heat source (BHS) of heat pump is a vertical ground heat exchanger in the form of 3 boreholes, each of which have a depth of 70 meters. In each borehole with diameters of $135 \mathrm{~mm}$, a single polyethylene U-tube was mounted. The boreholes were made in one line, with 7 meters intervals and at 6 meters distance from the northern 
wall of the building. The intermediate fluid in BHS is brine ( $40 \% \mathrm{v} / \mathrm{v}$ aqueous propylene glycol solution). Heat generated by the heat pump is accumulated in the buffer tank with a capacity of $1500 \mathrm{~L}$ or/and can be delivered to the air supplying building rooms by additional heat exchanger in air handling unit.

The fluid temperatures were measured by temperature sensors with platinum resistance sensing element Pt 1000 belonging to accuracy class A according to EN 60751. The volume flow rate of water was measured by dry running single-jet meter and for brine dry running multi-jet water meter. Both were equipped with transmitters of electric pulses. Flow rate measurement error for the flow of water bigger than $200 \mathrm{l} / \mathrm{h}$ was up to $2 \%$. Flow rate measurement error for the flow of brine bigger than $480 \mathrm{l} / \mathrm{h}$ was up to $2 \%$. To measure the electricity consumption of the heat pump was used a three-phase electricity meter 3x65A EEM34ELC with accuracy class of $1 \%$. All data from the installation are processed and archived by two DigiENERGY control systems in a cascade control.

Detailed information about installation and its control system can be found in [20].

\section{Results and discussion}

Analysis of the heat pump's performance was carried out for three heating seasons from 2012, understood as the days from the beginning of September of one year to the end of May next year. The maximum temperature of the supply of the buffer tank by the heat pump was set at $44^{\circ} \mathrm{C}$. Therefore, the considered system is treated as an intermediate between the low and high temperature heating system. Peak heat demand for $\mathrm{CH}$ was covered by a biomass boiler or gas condensing boiler. In heating seasons, electric heater with a heat output of $6 \mathrm{~kW}$ installed in the heat pump was never once been used; therefore, the value of $P_{E}$ in the formula 5 and 6 is equal 0.

To present changes of heat pump's performance in each day of the heating season $2014 / 2015$ SPF 3 was used (Fig. 3). Subscript $d$ denoting that calculation of SPF3 was done not for entire heating season, but only for a given day of the heating season. In addition, a daily average heat flux extracted from the BHS was calculated from the formula (7):

$$
\bar{Q}_{\mathrm{BHS}, d}=\frac{Q_{\mathrm{BHS}, d}}{t_{d}}
$$

where

$Q_{\text {BHS }, d}$ - daily amount of heat extracted from BHS [kJ],

$t_{d} \quad-$ daily operating time of the heat pump in heating mode [s].

For much of the days during the heating season, high values of $\mathrm{SPF} 3_{d}$ (in the range from 3.4 to 4.2) were obtained (Fig. 2). SPF3 ${ }_{d}$ values below 3.6 were reported most often for days with small $t_{d}$ or $Q_{d}$ (daily amount of heat produced by heat pump) above $300 \mathrm{MJ}$. From the beginning of February 2015 when the $\bar{Q}_{\mathrm{BHS}, d}$ was in the range from 6.9 to $7.5 \mathrm{~kW}$ and the $Q_{d}$ got high values, $\mathrm{SPF} 3_{d}$ was greater than 3.6. In the first part of the heating season can be seen high values 
of $\bar{Q}_{\mathrm{BHS}, d}$ for which most likely is responsible forced regeneration (the so-called passive cooling) in summertime. With each passing day of the season $\bar{Q}_{\mathrm{BHS}, d}$ was decreasing (trend line in Fig. 2) due to the gradual lowering of the temperature of the ground surrounding BHS.
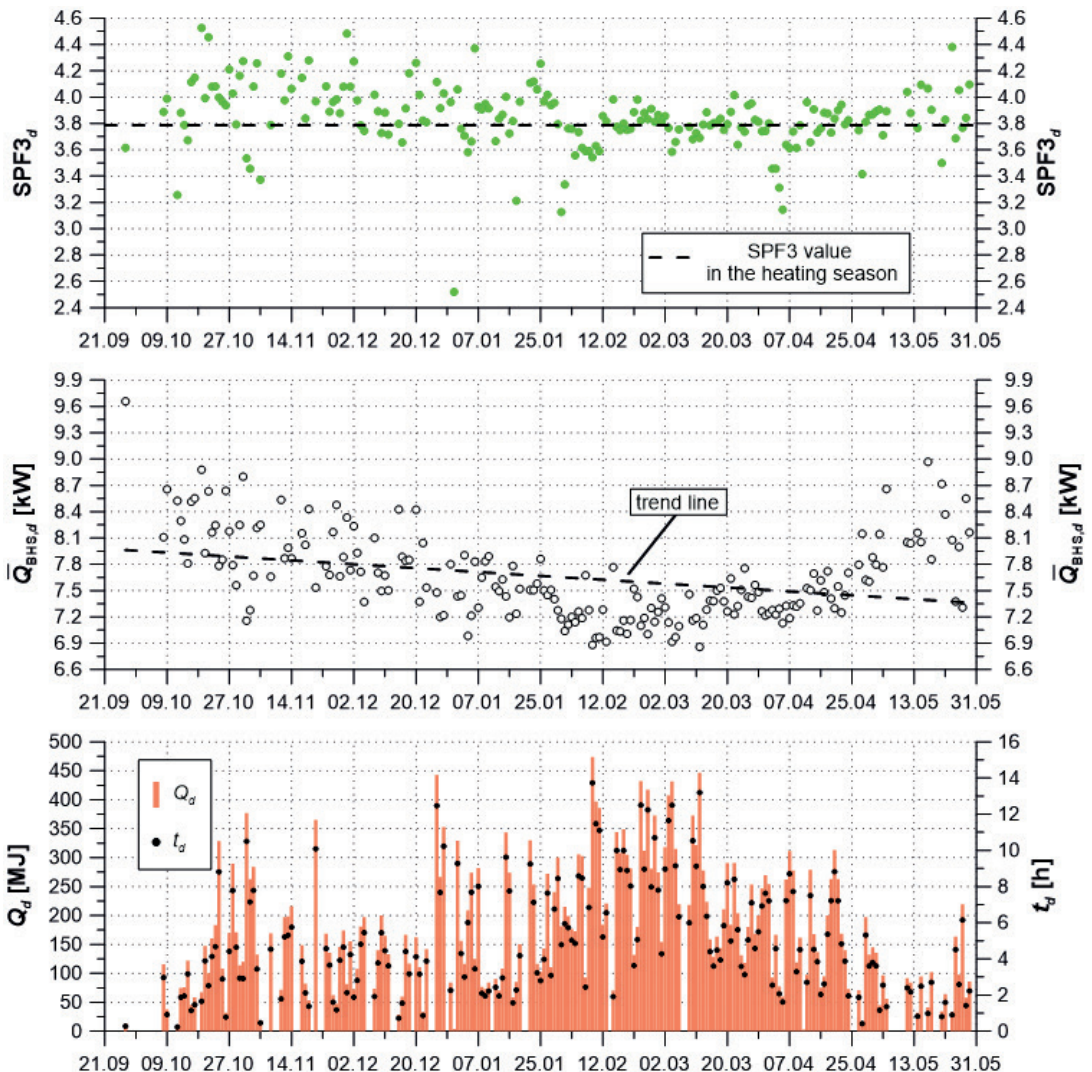

Day in the heating season 2014/2015

Fig. 2. Changes of selected parameters in the heating season $2014 / 2015$

In table 4 were summarised the results of the heat pump operating data in heating seasons. What is important, in each subsequent heating season average heating power of the BHS was a little bit bigger than in the season before. This fact means that in the BHS there were no adverse effects observed of physicochemical parameters of the soil surrounding the boreholes. The average heating power per meter of the borehole of approximately $35 \mathrm{~W}$ is a satisfactory result considering that the ground surrounding wells are composed of waterimpermeable claystones. The share of stand-by mode in the total consumption of electricity by the heat pump was (depending on operating time of the heat pump in heating mode during heating season) from 1.5 to $2.3 \%$.

The highest value of SPF3 equal 3.80 was obtained in the season 2014/2015. According to the technical data (Table 3 ) for considered heat pump value of SCOP for low temperature 
heating system should be from 3.75 to 4.38 , and for high temperature heating system should be from 3.13 to 3.75. As was written before, considered heating system is intermediate between this both, that's way the value of SPF3 obtained in real conditions can be regarded as satisfactory.

Table 4. Comparison of the results obtained in the heating seasons

\begin{tabular}{|c|c|c|c|}
\hline \multirow{2}{*}{ Description } & \multicolumn{3}{|c|}{ Heating season } \\
\hline & $2012 / 2013$ & $2013 / 2014$ & $2014 / 2015$ \\
\hline $\begin{array}{l}\text { Operating time of the heat pump in heating } \\
\text { mode during heating season }[\mathrm{h}]\end{array}$ & 1062.5 & 728.3 & 966.7 \\
\hline$Q_{S}[\mathrm{MJ}]$ & 38030 & 26927 & 34907 \\
\hline $\begin{array}{c}\text { Amount of heat extracted from BHS in the } \\
\text { heating season }[\mathrm{MJ}]\end{array}$ & 27880 & 19237 & 25877 \\
\hline$P_{\mathrm{C}}+P_{P}+P_{O}[\mathrm{MJ}]$ & 10303 & 7925 & 9178 \\
\hline Energy consumed in stand-by mode $[\mathrm{MJ}]$ & 152.3 & 183.7 & 148.1 \\
\hline $\begin{array}{l}\text { Average heating power of the heat pump in } \\
\text { the heating season }[\mathrm{kW}]\end{array}$ & 9.94 & 10.27 & 10.03 \\
\hline $\begin{array}{l}\text { Average heating power of the BHS } \\
\text { in the heating season }[\mathrm{kW}]\end{array}$ & 7.29 & 7.34 & 7.44 \\
\hline SPF3 & 3.69 & 3.40 & 3.80 \\
\hline
\end{tabular}

\section{Conclusions}

Already, special emphasis is placed on the solutions environmentally friendly and lowering the energy consumption in all areas of human life. That's way reliable assessment of energy efficiency of used technology is very important. It was shown that the value of COP calculated in steady state conditions can only be used to compare the technical specifications of heat pumps. This coefficient does not give full information about the performance of the heat pump in real conditions during the heating season. The recommended method is calculating SCOP according to PN-EN 14825. In the analysed installation during heating seasons $2012 / 2013$ and 2014/2015 were obtained SPF3 similar to SCOP which was described by the manufacturer in the technical data of the heat pump.

\section{References}

[1] Ercan A., Lieve H., Ground-coupled heat pumps: Part 1 - Literature review and research, Renewable and Sustainable Energy Reviews, Vol. 54, 2016, 1653-1667.

[2] Long N. et al., A review of heat pump systems for heating and cooling of buildings in China in the last decade, Renewable Energy, Vol. 84, 2015, 30-45. 
[3] Boghdal T. et al., Zarys aktualnego stanu wiedzy $w$ zakresie powietrznych wysokotemperaturowych pomp ciepła, Chłodnictwo i Klimatyzacja, Vol. 3, 2016, 40-45.

[4] Wachowicz-Pyzik A., Mazurkiewicz J., Możliwości rozwoju rynku pomp ciepła $w$ Polsce wświetle nowych uregulowań prawnych, Ecological Engineering, Vol. 44, 2015, 62-67.

[5] Miara M., Ograniczona wymowa wspótczynnika SPF, InstalReporter, Vol. 7, 2012, 9-10.

[6] Egg J., Howard B.C., Geothermal HVAC: Green Heating and Cooling, The McGrwa-Hill Companies, New York 2011.

[7] PN-EN 14511, Air conditioners, liquid chilling packages and heat pumps with electrically driven compressors for space heating and cooling, Poland.

[8] Malenković I., Review on testing and rating procedures for solar thermal and heat pump systems and components, Intelligent Energy Europe Project IEE/08/593/SI2.529236, Vienna 2012.

[9] Lachman P., COP dla pomp ciepła - wartości realne i te „niezwykłe” z prospektów reklamowych, InstalReporter, Vol. 7, 2012, 16-19.

[10] Lachman P., Metodyka obliczenia OZE $z$ pomp ciepla zgodnie $z$ najnowszymi wytycznymi UE, InstalReporter, Vol. 3, 2013, 42-47.

[11] PN-EN14825, Air conditioners, liquid chilling packages and heat pumps with electrically driven compressors for space heating and cooling - Testing and rating at part load conditions and calculation of seasonal performance, Poland.

[12] Danish Energy Agency, Calculation of SCOP for heat pumps according to EN 14825. http://www.eceee.org (access: 2.05.2016).

[13] Directive 2010/30/EU of the European Parliament and of the Council on the indication by labelling and standard product information of the consumption of energy and other resources by ErP, http://eur-lex.europa.eu (access: 2.05.2016).

[14] Zalewski M., Klasy pomp ciepła Nowe regulacje europejskie, InstalReporter, Vol. 10, 2015, 27-29.

[15] Mirowski A., Podręcznik dobrych praktyk na bazie szwajcarskich $i$ polskich doświadczeń w zakresie wykorzystania odnawialnych źródet energii, Związek Miast i Gmin Dorzecza Parsęty w Karlinie, Karlino 2014.

[16] Lachman P., Spór o minimalna wartość SPF $w$ dyrektywie OŹE, Polski Instalator, Vol. 3, 2010, 78-83.

[17] Miara M., Sprawność pomp ciepła w realnych warunkach użytkowania, InstalReporter, Vol. 2, 2011, 12-16.

[18] Miara M., Wyniki badań dolnych źródet ciepta w pompach ciepła typu solanka/woda. InstalReporter, Vol. 10, 2011, 11-16.

[19] Miara M. et al., Heat Pump Efficiency Analysis and Evaluation of Heat Pump Efficiency in Real-life Conditions, http://wpeffizienz.ise.fraunhofer.de/download/final_report_wp_ effizienz_en.pdf (access: 2.05.2016).

[20] Pater S., Chłodzenie pasywne $z$ wykorzystaniem instalacji hybrydowej $z$ odnawialnymi źródłami energii, PhD thesis, Kraków 2015. 